\author{
47. \\ $616.24-002.14$ \\ 所謂一過性肺浸潤症 (sog. flüchtige \\ Lungeninfiltrierùng) / 2 例

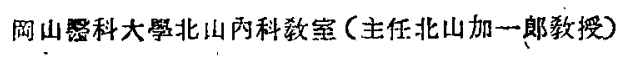 \\ 副手 淛學小本潔
}

[昭和 17·年这月 17 日受稿]

\section{緒 霑}

Assmann / 所謂 Frühinfiltrat‘ガ極ク良好ナ 經過 シトル時ハ, 生ジタ浸潤ガ速二消失シ全ク痕

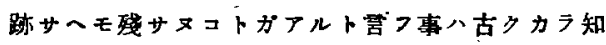
ラレテ居ル. 勿論，早期浸潤八第二次結核感染 $=$ 燐スルモノデアルガ，第一次感染二虚スル所謂 Epituberkulose モ亦極多短時日；間二完全=其 ，除影ガレ線检查上消失スルコトガアルト言フ束 ニ就イテモ而成古クカラ知ラレテ扂几。作シ作ラ

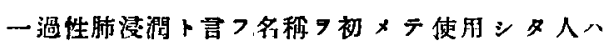

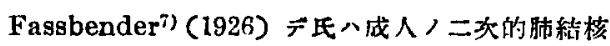

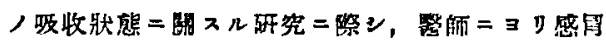

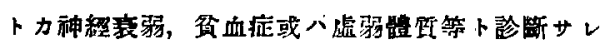

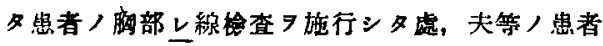

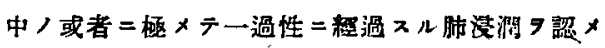
$コ レ 9$ flüchtiger Lungenprozess ト名付ケテ訅 载シタノデアル，賞時氏八其ノ本態习結核二还人

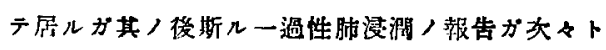

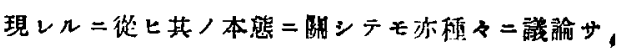
レ，結核說 =䈍成スル者モアレパ及非結核性デア ルトスル者，特二非定型的肺炎二你ルノデァルト

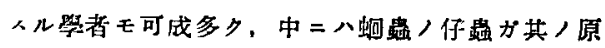
目デアルトヘル者サーフリ，又花枌其，他何カ不 明ノケアレルダン」=依ル過敏症=其，原因 モノモアル. 特=1932 年 Jöf(ler ${ }^{18) か ゙ ェ ォ シ ゙ ン 」 ~}$

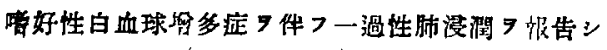

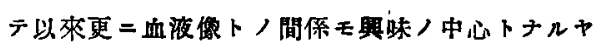
ウンナッタ.

本邦ニ於テモ既＝數名ノ學者二依り䟢售サレテ 八居几ガ，余モ亦最近當科入院患者 $=2$ 例 $/$ 本症

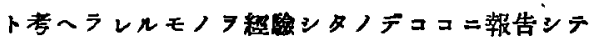
諸家ノ批判 9.仰グ次第デナル。

\section{本症ノ文狱二關スル總括的展望 站二考察}

1920 年 Eliasberg 11. Neuland $\left.{ }^{31}\right) 八 2$ 歳乃至 4 歳ノ小兒デ䠦牀症状ガ左程著明デカイくニカが

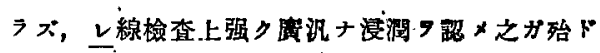
總テ度性デれニ八餘程短時日間二吸收サレデシ フモノモアルト言フ事 7 琵表シ, Gipituberknlose

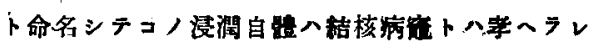
又ガ結核感染兒ニノミ來り結核卜密接ナ网係甲有 スルノデフルト茺へテ居几．共ノ传小兒二來ル

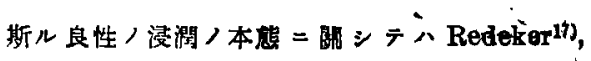
Engel 等, 病篗周圈炎說ガ久シク信ぜラレテ居

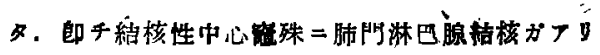

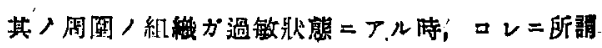
tuberkulö-toxiech / 刺戟ガ加ルト其ノ反雄トシ テ中心篗カラ周同/方迄炎街ガ波及シテ非特異珄

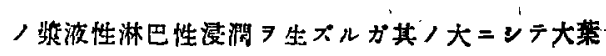

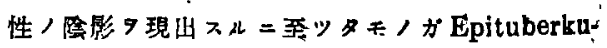
loseデナルト寺フノデナル. コレ゙= 1936 年 


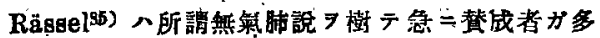

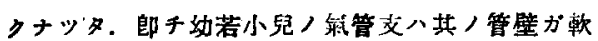

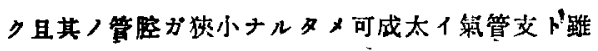

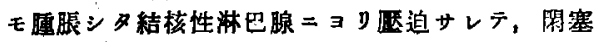

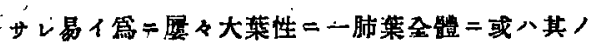

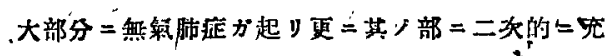
血、出等习來シテ鋥影习形成スルモノデルト

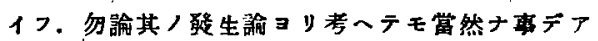
ルガ Eliasberg u. Neuland / Epituberkulose

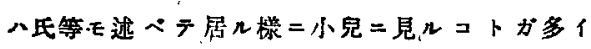
ノデアルガ成人二モ時=来ルコトがアルモノデ Sonnenfeld ${ }^{101}$, Schellenberg ${ }^{11)}$ 等吕斯几成人 症例の報告シテ磨ル。

要スルこEpituberkuloseトシテ總括サレル主， トンテ小是二多ク見ラレ几艮性，肺浸㵎八第一次

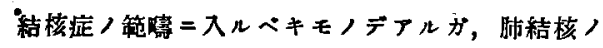

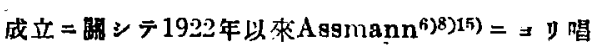

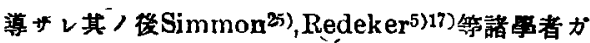
迫補改良シタ所謂早期浸濶ナルモ广八营然第二次

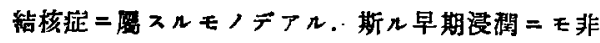
常=良性デ短期間內二吸收サレルモノガフルト言 フコトヘ氏等モ迅ベテ居ルシス Kleinschmidt ${ }^{9}$,

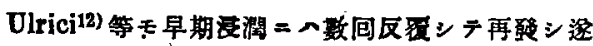

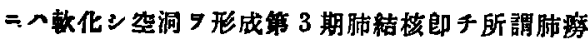
シ移行スルモノモナルガ又容易二吸收をフレル性 蛽有スルコトワ迅ベテ居ル。

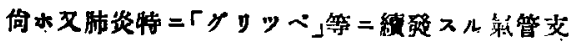
肺炎ノフルモノデハ症狀極ク少ク早期浸潤ノ甚シ

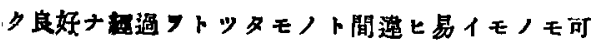

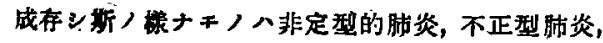
渄特極性肺炎等ト記サレテ居ルガ, コノモノ八症

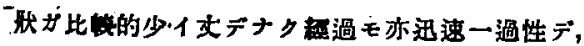

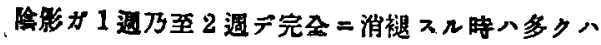
非定型的㖑椪卜考へテョイトイフ(山田氏日1)）小

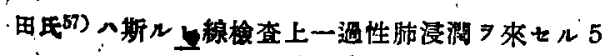

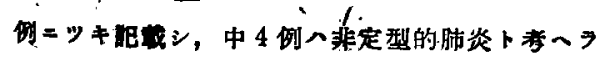

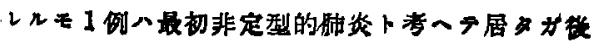

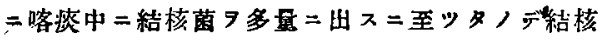
性ノモノデアッタコトが明ニナツタ例 站告シテ 居ル.

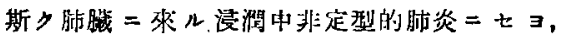
Epituberkulose $=$ 七 3 或八早期浸溜,Tendeloo2t) , 言 $>$ kollaterale Entzündung, Ranke, Perifokale Entzündung $=\longleftarrow ヨ$ 容易二短時日，

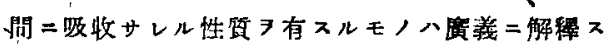
レバ其ノ結核性ダル非結核性タルトラ間八ズ何 レモ一過性肪浸閏ト言七得几モノト考へラレル。 解シ乍ラ兓二緒言ニテ逝へタャウニ初メテ一過

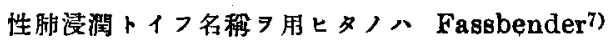
(1926) デ31 例 一括辄告ンテ居ルガ为 8 例八1 ケ月以丙二隍影ノ消失セルモノデ特二最モ速ナル ハ8日閒 ニテ既二消褪シテ居ル、而シテ氏八斯ル 一渦性肺浸潤ノ本態

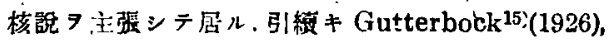
Birk u. Hager ${ }^{1)}$ (1928) 等 / 報告 $ァ$. 特= Birk

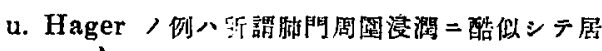

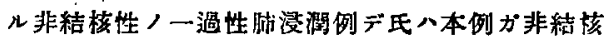
性ナル根據トシテ「ッヘルクリン」反應ガ除性デフ ツタ點ワ强蒴シテ居ル。

1932 年 (üfffler ${ }^{18)}$ ハ一過性肺浸潤ニ「ェォジ フヘリー」ヨ伴フモノガ多イ點二初メテ注意

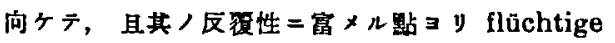
succedan Infiltrate mit Eosinaphilie ト命名シ 斯ルモノ5 例 9 裉告シ其ノ本態 9 内 2 例八症狀 - 少イ捕炎(klinisch symptomärmste Pneumonie) =，他ノ3例八結核性ノモノデアヘトト結諭ンテ居 ル. 然ル = 1936 年 氏 $^{23}$ ) 登表二侬几ト近時氏 八斯几浸澗 9 皮店二於ケル Tuberkulide =相當 ス肺腧，Mikrobide 即チ結核䓢侵入二数スル

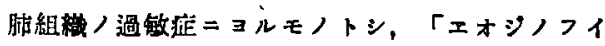
リー」八斯ル過敏症ノ存在 7 示スモノニ他ナラズ

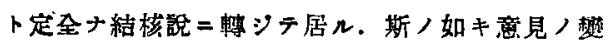

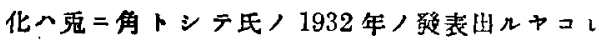

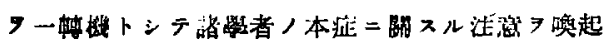




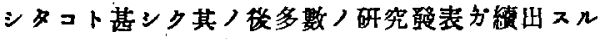

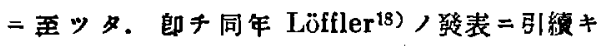
Boytinck $^{19)}$, Kellner ${ }^{20)}$ ノ報告がアル. Boytinck

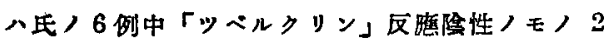
例，弱陽性ノモノ 3 例，陽性ノモノ1例ナリトテ 肺㱓ノ一過性浸潤へ必ズンモ結核性デハナ1，非 結核性ノモノモアル，Fassbender ${ }^{i} /$ 例ノ中 = モ必ズ非結核性ノモノモ混ジテ居ルデアラウト 括一，Kellner ${ }^{20)}$ 八結核性卜非結核性卜，鑑別=

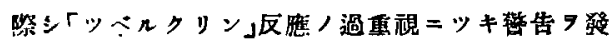
シテ居ル。

1933 年 $=$ Hochstetter ${ }^{21}$ ) /與味フル2例 一過性肺浸潤二就イテノ訅戴 $尹$ 見ル。第 1 例八相 當長期間肺結核トシテ治療 其ノ浸潤瑟化ノ枋レアルが篇二人工気胸療法 7 施

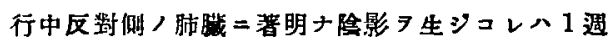

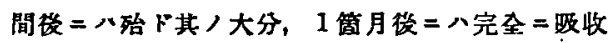
サレタトイフ. 次八結核相談所二勤枒ソテ居タ健

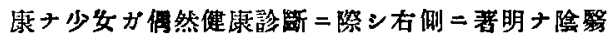
ヨ認メタガ約2崌間後ニ八全ク吸收サレタ例デア 几，而シテ第 1 例デ八患者八既二結核性矣患 7 有

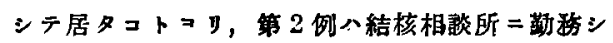
テ居ルコト、リ推测シテ共二早期浸閏が甚シタ良

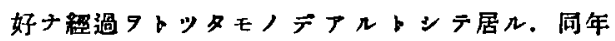

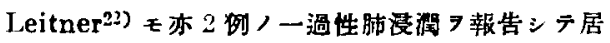

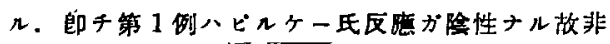
結核性デフルトシ第2例八結核性ノモノカ非定型 的肺炎カ何レトモ決定出來又卜进へテ居ル。然ル $=1936$ 年氏 $\left.{ }^{32}\right)$ 珰chtige hyperergische Lungeninfiltrierung mit Fosinophilie ナル题デ結 核高度「アレルキーー」基图ン「ェォジノフィリー」

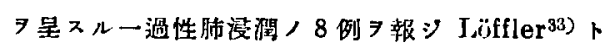
杀ク间总見ニテ本症ノ本㹂トンテ結核性タルコト

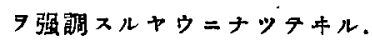

次ニ「アレルギー性」疾急トノ相网性》再視ンタ

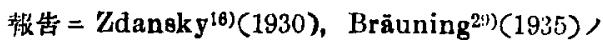

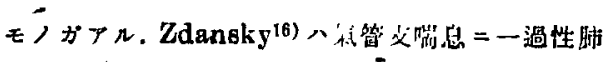

浸潤

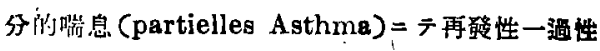

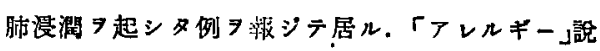
ブ面白イノ八Engel ${ }^{0)}(1935)$ ノ花粉說デアル. 氏ハ上海デ俗= Privet coughト呼ベレルモノガ 本症狀群 $=$ 相當シコレハ7月, 8 月ノ頃 $=$ 盛ン 花粉 一性疾患デアルト言ヒ、Meger ${ }^{42}$ (1937) モ亦コ

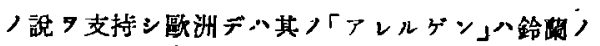
花粉タト言フ。

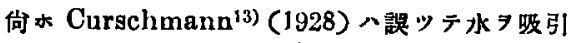
ンタタメニ生ジター過性肺浸潤 7 報告シテ居ル。

其後毛々，原因二因ル一過性肺浸㵎が教告

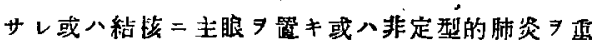
視ンテ居ルガ，厼小興味アル馀トシテ 1934 年二

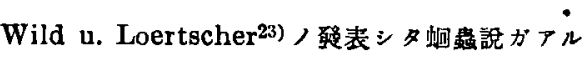

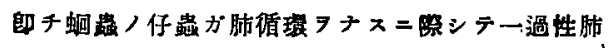
没洞 7 起スノョ認メタト言フノデアル. Müller43 (1938)八 60\% =モ達スル「エオジノフィリー」习 星シ蜔蟲=基因スルト考へラレル例习報シ，タト 一屎中蜔踽卵或八是䯠 トスルモ恐ラク一過性肺浸潤，原因八䖲盛=コル モノト信ぜラレル由ラ說キ，且斯ル一過性肺浸潤

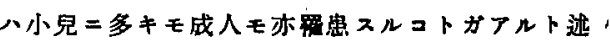
ベテキル. 然ル = Eversbusch ${ }^{\overline{45}}(1939) ハ コ /$ 蜔

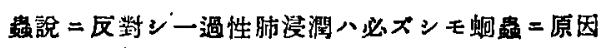
ヨ有スれモノ=非ズトテ Leitner ${ }^{32)}$ )結核 $=コ ル$ 高度「アレルギー」誈.(hy penrergiscbe Lungen-

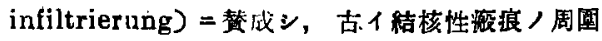
二何等カノ原因二對スル「アナフイラキンー性反 㦄トシテ起ッタ umschriebenes anaphylaktisch bedingten kollateralen Odem. der Lunge $\vec{F}$ アルト寻ッテ居ル。

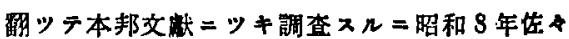

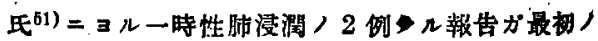

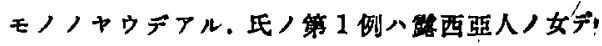

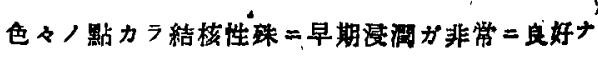


程過 菌ガ證明サレタ點カラ結核性ナルコトハ闻造ヒナ ク本例玉亦早期浸潤ガ好都合二湓過シタモ，ト考 ヘラレルト述ベテ居ル。然ル＝岖均八昭和 12 年 今度八非結核性卜思ハレルモノ3例タ派告シ珠二 中 2 例ハ「ダッッバ」性ノ一特性肺浸閣デフラウト 言七本症二八結核性ノモノ及ピ非結核性ノモノノ 雨者ノ存在スルさト9肯定シテ居ル.

昭和 11 年管田氏 ${ }^{523}$ 八全身化总感，一頂浦，食欲

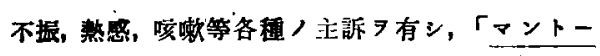
氏反應性デ11日乃至 35 日ノ間二完全二消褪シ タ一過性肺浸潤 7 例 7 總テ非結核性ノモノナリト

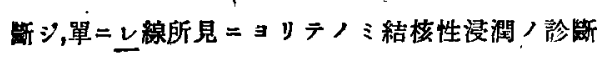

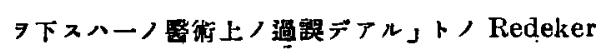
ノ言葉フ引用ン臨牀上「ッペルクリン」反踟ノ重要 性 ア强調シテ居ル。

昭和 12 年竹川氏日5)モ亦「グリッン」」症狀ジ始 り「メォジノフィー」ア旺シナイ非結核性一過性 肺浸潤 1 侧 7 記載シテ居几。

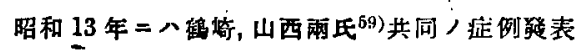

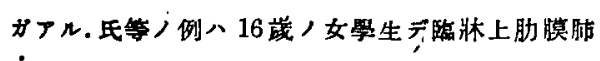
炎ノ症狀

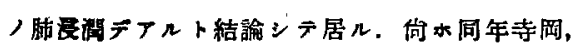

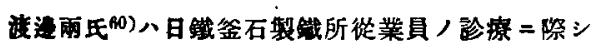

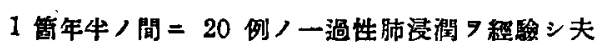
等/症犾等詳細二絬計的表 7 行ッテ居ルガ、氏 等 $=$ ヨルト男子 $=$ 多々且特期八初夏及ビ初

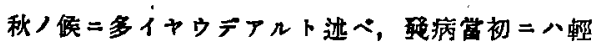
度/白血球塯加 7 認メルモ間モ無ク正常做二復ン rエオジン啫好性」白血球八白血球数㙁加ノ時期 $=$

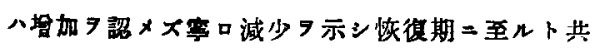

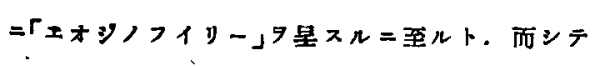

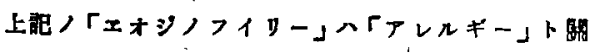

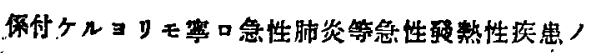

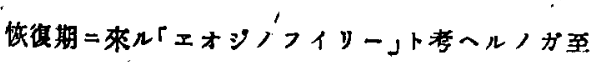
裳デヘナイカト进デ居ル。

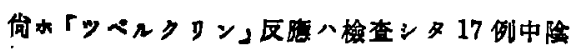

性 11 例, 皆性 6 例デアッタガ玟性デアッタモノノ

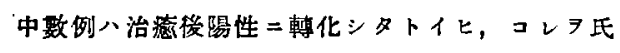

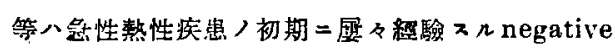

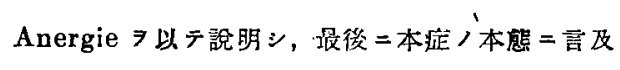

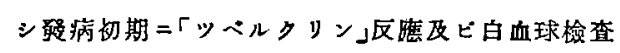
$\boldsymbol{7}$ 施行ス之バ結核性浸潤卜所謂非定型的肺炎卜ノ 鑑別二㗄スルコト大デ殊= negative Anergie 7 登明スルヤウナ例八非定型的肺炎デコレ=反シ初 期ヨッ「ッペルクリン」反䂼が著明二陽性二出ル例 八結核性ノモノデアラウト述べテ居ル。

同年 =八更二小松氏61)，岩田氏62)，就告ガアル。 小松氏 ${ }^{(1)}$ 八大連保健所デ 1 简年間 = 一過性胸部隍。

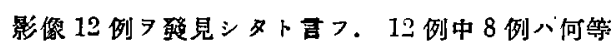

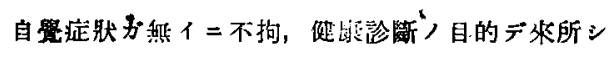
登見サレタモノデコノ點八誠二興昧アル事ト考へ ラレル：本浸洞ノ本態 $=$ 關シ 12 例中 10 例八非定 型的肺炎 =婹ズルとデ他ノ2例八如何ナル性丝 ノモノカ不明デアルト。

コレン反シ岩田氏ン八東大收口內科二テ緦驗り タ一過性肺浸潤 14 例二就キ其ノ本態二關シ灾ノ

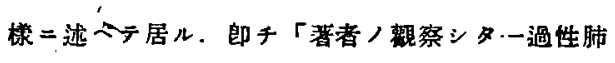
浸潤八結核性卜認ムベキモノガ多イガコレト同㥞 ナ上線像八結核以外，原因 $=\Xi$ リテモ起り得儿故 個々，例二就けテ其，何レ二焉スルカョ決定スル コトハ多ク，場合困難デアル」ト，佮水氏ノ 14 例

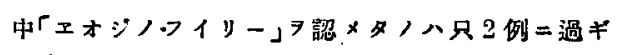
ナカカッタト言フ。

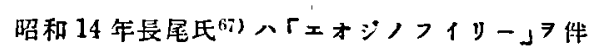
フ一過性, 肺浸閵 712 藏, 男子=㴽验 シ, 竹谷

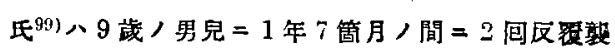

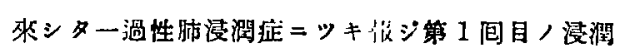

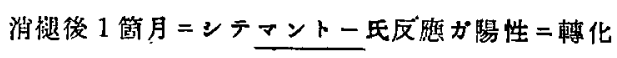

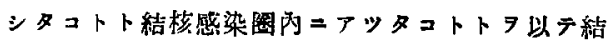
核高站「アレルギー」= dung デアラウト述へテ居ルガ血液检盉八1间モ， 施行シテ居ナイ故「メオシノフィリー」ノ有然心合 ク不明デアル。 
桪和 15 年岩本氏71皇亦「ェオジノフィリー」ヨ

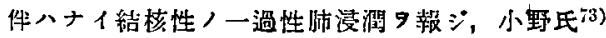

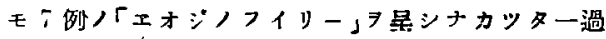

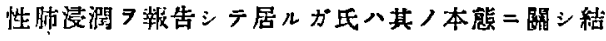
核性ノ疑七浱厚ナリトノミ記シ斷定的ノ絬論

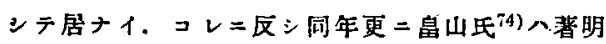

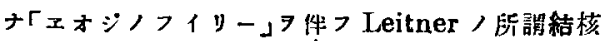
高「アレルギー」ニ基ク一渦性肺浸洞症 ヨ報告シテ 居ル。

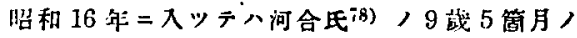
少女二見タ「ホジフくリー」ア伴フ本症ノ1例

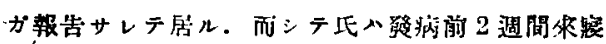

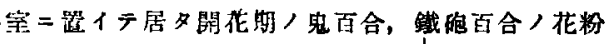

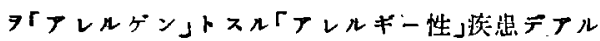
ト諭ジテ居ル。

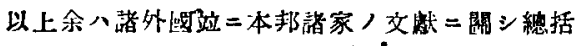

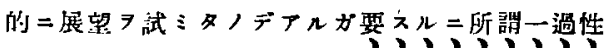

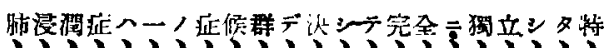
筷疾病デヘナイ・

Jöffler $\left.{ }^{33}\right)(1936)$ 八本病 /特微トシテ, 「(1) 急

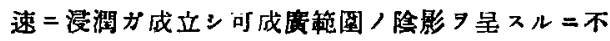
拘速二消腿スルコト（2）血液像ニ「ェォシノフ

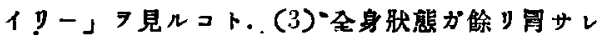
ナイコト.」/ 3 愐月 7 㦛ゲテ居ル. 勿論第 I / 項

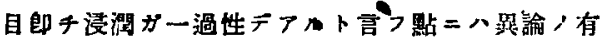

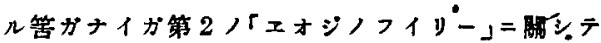

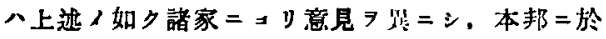

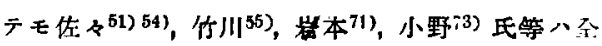

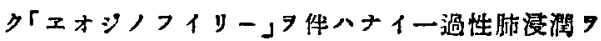
報告ン岩田氏62，14例中ニ於テモ「ェオジノフィ

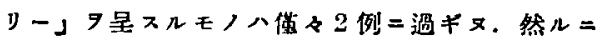

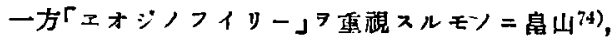
河合氏 ${ }^{9 R}$ 等アリ，特=河合氏，如キハ「ェオジ，

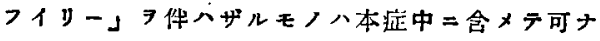
ルヤ猚木檢討ノ俆地アリトサ一極言ンテ居ル.

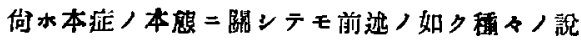
ガアルガ，要 スル二結核性卜非絬核性 $=2$ 大別出
來，非結核性ノ原因 7 主張 $ス 几$ 者八更二非定型的 肺炎說，非結㤥性「アレルギー」誢，蜔䩶镜二分ヶ 得ベク尗ダ沈シデ主シテへ居ナイ。

\section{臨 牃 例}

\section{第1旷}

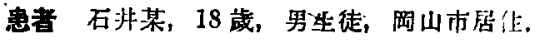

初喰昭和 16 年 6 月 26 日，䬣日大院.

声泝 高熱。

家族歷 雨親共二健全，虫者八 4 人兄弟中八第

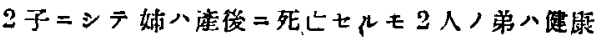
Fフル.

饭往㕍 特記スベキコトナシ。

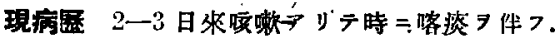
1.昨日登校セシ =午前 11 時頃頭痛, 惡感 7 以

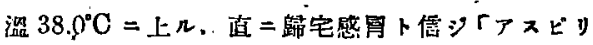

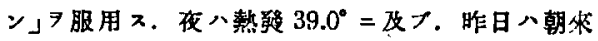
高熱てリ $\left(38.5^{\circ}-39.5^{\circ} \mathrm{C}\right)$ ，解ンケラ高㷊ノ制二身

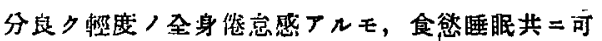
成良好，時二㖟雅アルモ極ク俓度デ別二苦痛デナ

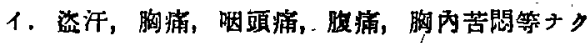

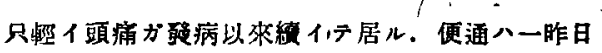
以棵末ダニナシ。

現症 身長中等大，策粪良好ニジ筋肉，皮下

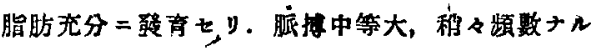

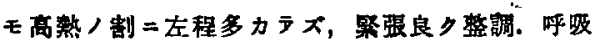

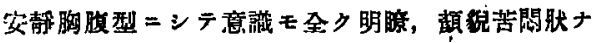

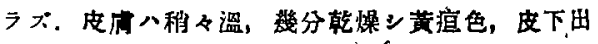

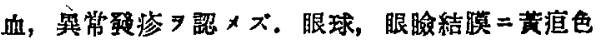

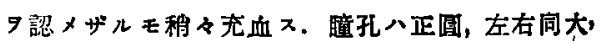

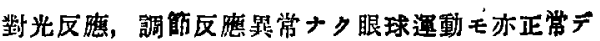
フル。舌ハ稍々乾嬠ン中央部二白色ノ舌苔可成り ノ程度=存 ス。洇頭部科々充血スルモ扁桃腺ニ八 異常ナク頚部淋巴腺ノ䛲脹モ琶メ又。

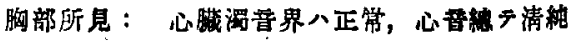

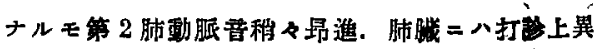

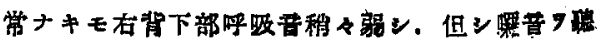




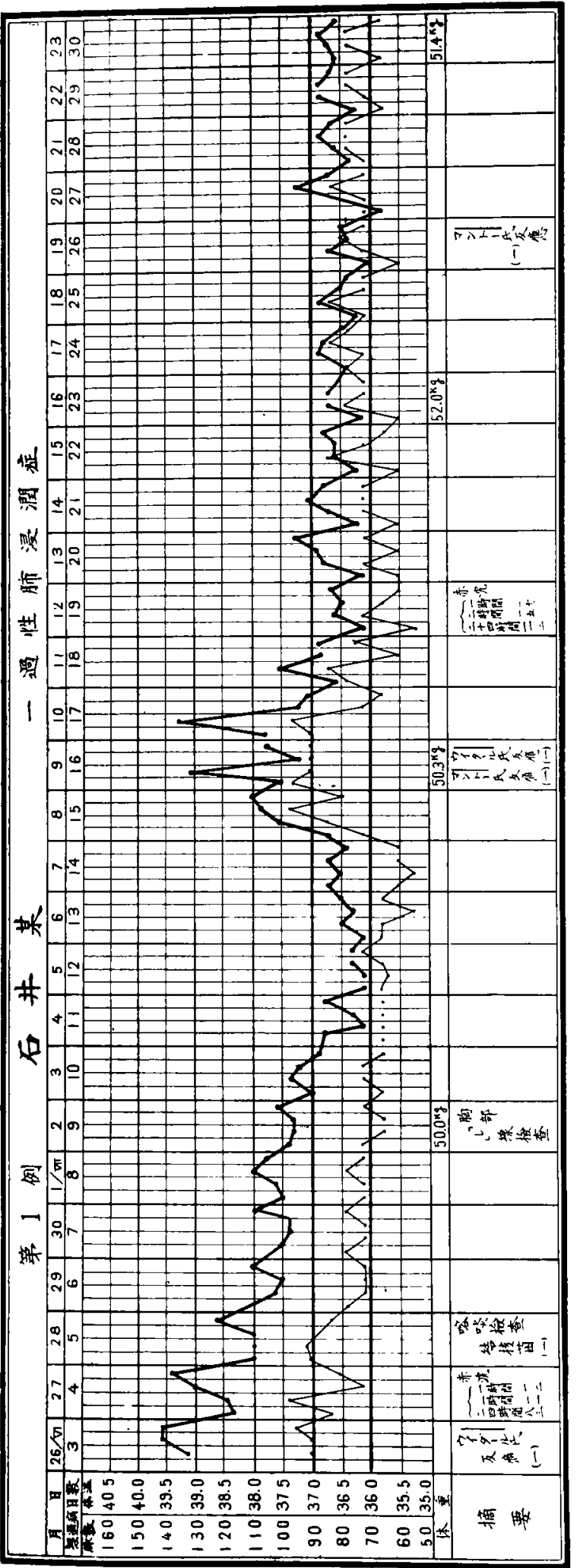

取七ズ.

吰部所見：平坦ニシテ柔㳄，肝裁， 觜䑏

四肢：運動及ビ知妾障碍ナタ滕蓋践 反射モ亦善常 シ.

入院後正二次ノ諸检查 $\mathbf{9}$ 行フ.

1) 血液像：血色甞73\%(ザーリー), 赤血球数 416 萭，白血球數 10250 ，白血 球ノ媑類八中性嗜好性 $61 \% \%$, 淋巴球 $29 \%$, 大骂核 $10 \%$ ニシテ「エオジン嗜好性」白 血球ハ全クコレヨ認メズ.

2）亦血球沈降速度（ウェステルグレ ン氏法)：1時閏 13,2 時間 21,24 時間 83 ニテ种々く促僬.

3)ウィダール氏反應, ワイルーフェ リックス氏反㦄：共二良性ナリ。

4)喀痰中結核菌 检出セ ブ.

5) 尿, 屎: 尿八淡黄色登明, 比重

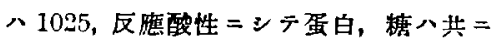
陸性、「デアゾっ「インデカン」「グメリ ン」反鷹篮モ亦险性ナリシモ,「ウロビリ ン」「ウロビリノーゲン」反胣共 $=$ 弱䧂

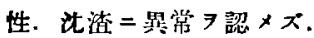

入院後, 䋑過站二諸检查成結：

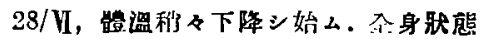

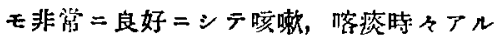

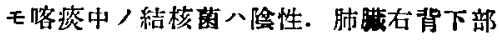
呼吸音弱キノミニテ罚学音 咅ヨ證明セズ. 本日便通フリ，检鈿セル モ䖪䀦 7 認メズ。

2/䜣，在望，第 7 胸椎，高サ／部二極 ク少数ノ小水泡吾 9 聴キ且該部二弱キ的

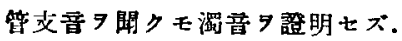

胸部上線像(第 1 圆) 所見:

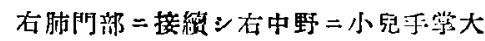

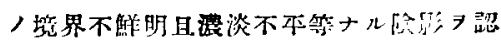




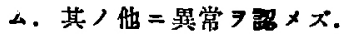

第 1 圖 症例 1 石井某 (昭和 16 年 7 月 4 日)

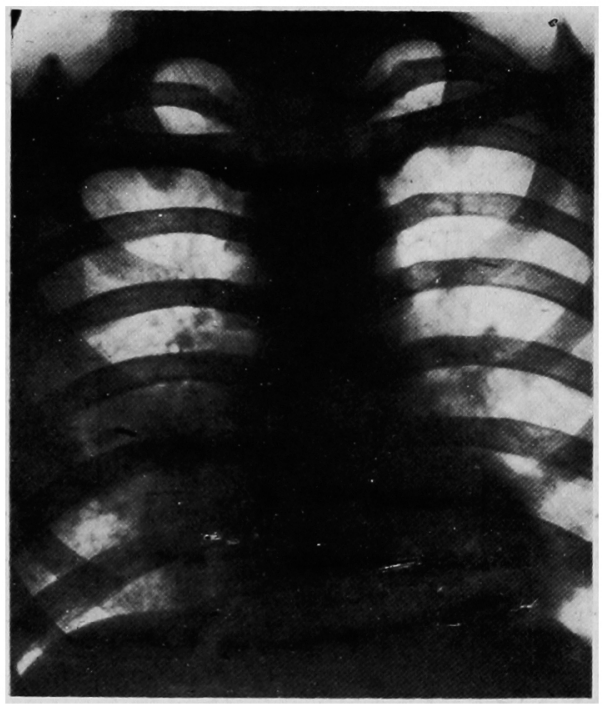

4/VII，本日完全二解熱シ全身狀態忩々良好

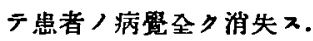

$8 /$ III, 再度登整 $38.0^{\circ} \mathrm{C}=$ 及ブ。

9/VI, 胸部所見：左胸部八打㯖垓上正常，右

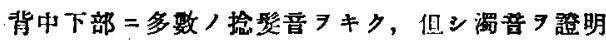

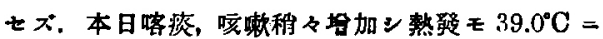
及フ十。

ウイーダール氏反應：㟏性.

アルトー氏反媳 (2000倍)：隍性.

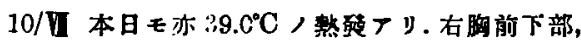
右背下部共二昨軋音，小水泡音习㯖》。

12/U，再ビ完全二解熱シ患者八氣分良好 ニテ， 会愁旺盛ナルモ喀资，唤濑八依然存 ス。

赤沈速度：1時間 27，2時間 57，24 時間 113 テテ中等度促 $\boldsymbol{二}$ 示 .

斯クンテ楆渦良ク以來全ク平整ラ緅ケ7月下旬

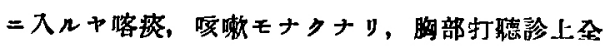
ク整化可認メザルニ至ル。

19/V， マントー氏反墌 (1000 倍)：隆性.

28/V，胸部上線像（第 2 圖）所見：
第 2 圖 症例 1 石井某

(同月 28 日)

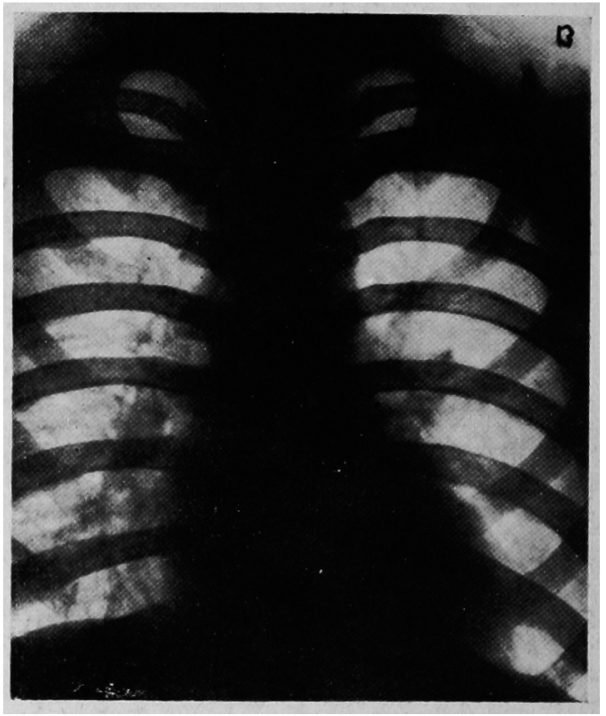

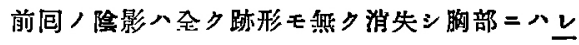
線檢查上何等ノ罢常

血液像：血色素 $72 \%$ ，赤血球数 369 萬，白血 球数 6200 , 白血球／秏別八中性啫好性 $50.5 \%$ ，淋 巴球 $32 \%$ ，大單核 $9.0 \% ， r_{x}$ オン嗜好」白血球 8.5\% シシテ「ェォシノフイリー」ラ是ス。

マントー氏反應 (500 倍)：隍性.

$31 /$ WI，赫此速度 1 時間 $3 ， 2$ 時間 $9 ， 24$ 時間 54 シシテ全ク正常トナル.

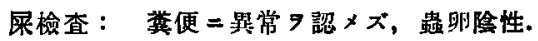

斯クシテ忠者ノ全身將態八忿々良好トナリ娟重 モ亦入院時二比之稍々搖加，本目全治退院 ス。

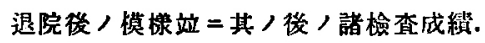

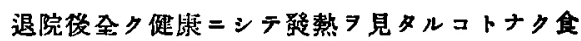

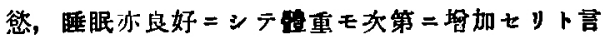
7.

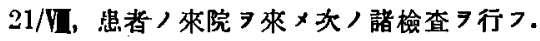

1）血液像：血色菜 $79 \%$ ，赫血球数 425 萬， 白血球數 6000 , 白血球，種別八中性啳好性 $62 \%$ ，

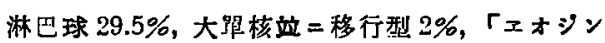

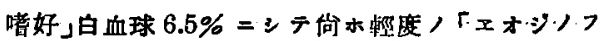
イリ一」7旺ス. 
2) 赤沈速度：1 晊間 3,2 時間 9,24 時間 56 ニンテ正常.

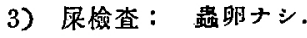

4) マントー氏反應 (500倍)：除性.

5) 胸部上線像(第 3 圆)：何管人暴常所見ナ *.

第 3 圖 症例 1 石非㷊

(同 8 月 21 日)

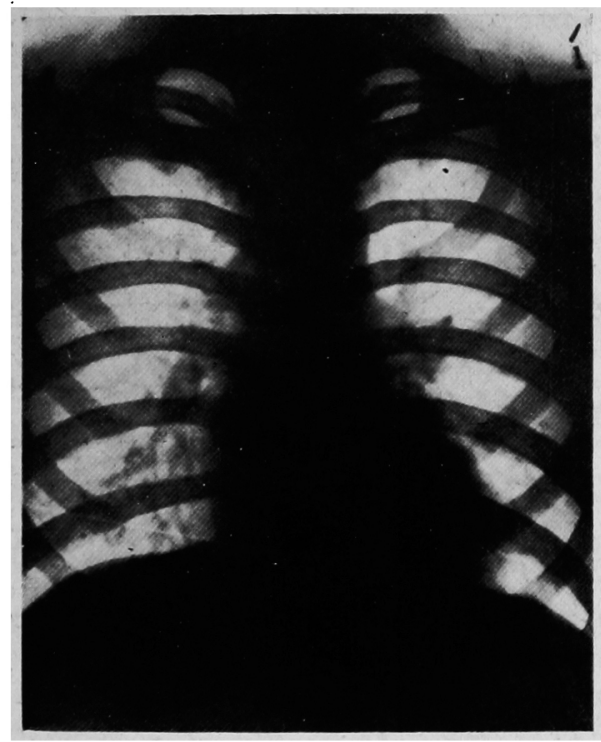

6/IX，再度点者ノ來院 7 求么。

1) 血液像：血色素 $82 \%$ ，赤血球数 4.35 萬， 白血球數 6400 ，白血球／種別八中性嗜好性 $64.5 \%$ ，

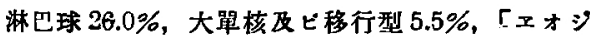
ン啫好性」 $4.0 \%$ =シテ血液㩍へ会ク正常ナリ. 2) マントー氏反詐 (100倍)：陰性.

\section{象2 例}

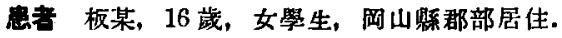

初馀昭和 16 年 5 月 5 日.

入晩 昭和 16 年 6 月 2 日.

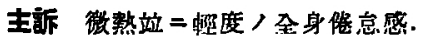

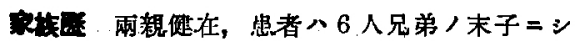
テ長妃ガ 39 歲 $=$ テ䐉膜炎 =テ死しセル他總テ健
在ナリ。

既往定 6 歲ノ頃中耳災二椎患せシ他著患 7 知 $\exists$ ズ.

現病歴 4 月中旬學校/身體檢查二繁シ微熱 7 發見注意 7 受ク. 以來斯ル微熱去ラズ 5 月 5 日常 科 7 訪レ胸部レ線㭘查 7 受々(第 1 阔) 休校, 安 䟹 ヨ命ぜラレ自宅ニテ休羡シ居ルモ微熱依然去ラ ズ, 6 月 2 日當科 $=$ 入院. 以前 3 リ嗄濑, 喀痰殆

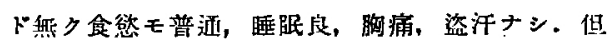
シ 5 月初旬 $\Xi y$ 全身僚怠感輕度ナルモ存ス。月經 八昭和 15 年 9 月開始, 以來略ボ䚁則正シク每月來 潮スト急つ。

現症身長中等大, 穊肉, 皮下脂肪可成登育シ 策善这好ナリ. 脉搏秒々頻数ナルモ緊腲良ク整調.

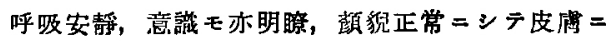

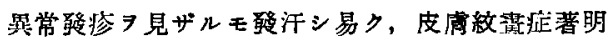
二㳢性. 眼球, 眼瞼結膜正常ニシテ黄渲色, 筫血

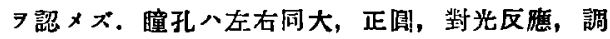
筋常ナク眼球荤動及正常. 舌八濕潤，薄キ舌苔二 覆ヘル，咽頭部二異常ナク到部二病的淋巴腺腫腫 脤 ヨ䚪レザルモ甲狀腺極ク堭度二腫脹七ルヤノ感 $>y$.

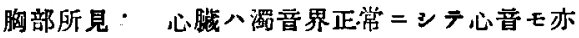

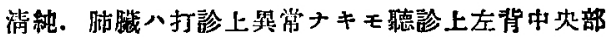
二極ク少数ノ水泡音 7 㯖ク.

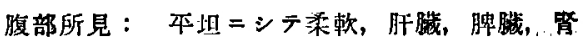
臟等 7 觸レズ.

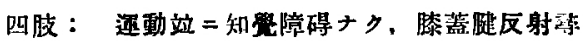
常. 腓媵漩ノ握痛 9 證明七ズ.

- 5 月 5 日外來浐察時所見 :

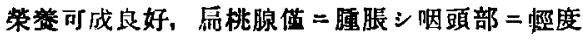
ノ充血フリ．甲畎腺腫輕度ナルモ㒛メラル．心䑏

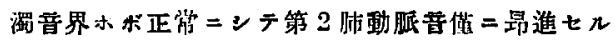

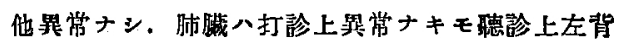
中央部二的ク少数／捻筑普 滕箩踺反射モ亦正常ナリ。

胸部上線像(第 1 圆) 
第 1 圖 症例 2 板某

(昭和 16 年 5 月 5 日)

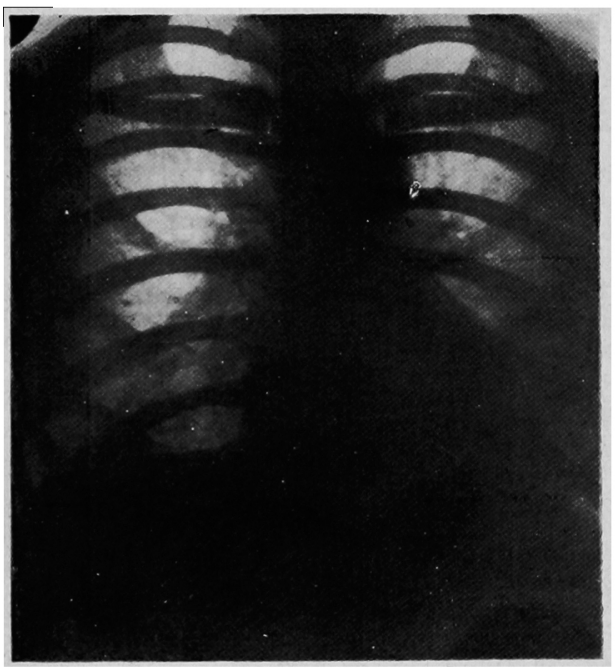

左側中下肺野ニワタリ小兒手掌大ニシテ境界不 明瞭，浱淡相混合七几モ全體二秒々軟キ感 7 興一 $n$ 险影习認么. 其)他 $=$ 特記スベキ所見ナン( 5 月 5 日).

患者 6 月 2 日入院直後，諸檢查成績.

1）血湤像：血色素 $58 \%$ ，告血球數 378 萬， 白血球数 7700 , 白血球，種別八中性㗪好性 $57 \%$, 淋巴球 $38 \%$ ，大晸核及ビ移行型 5\%，「エォジン 㗪好性」白血球へ全クナン。

2) 赤汇速度：1 時間 15,2 時間 28,24 時間 98 ニンテ秒々促進七り.

3) 尿, 屎：尿八淡黄色澄明, 比重 1030 , 反 應中性，蛋白，糖へ共二隍性、「インヂカンむ゙グ メリン」「「ウロビリン」,「ウロピリノーゲン」。

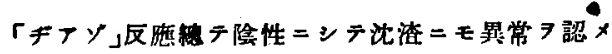
$x$.

4）、ントー氏反應 (2000 倍)：䧝性.

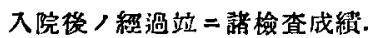

$3 / \mathrm{I}$ ，午後二八 $37.0^{\circ}-37.3^{\circ} \mathrm{C}$ ，徽繁厂リ．且稍

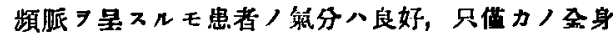

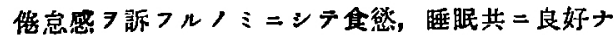
リ．本日喀痰中/結核菌 7 精查セルモ陰性. 胸部

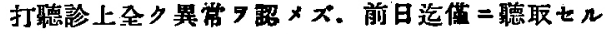
右背中央部／小水泡畐全》消失七刀。

用部上線像 (第 2 圆).

第 2 圖 症例 2 权葉 (同 6 月 3 日)

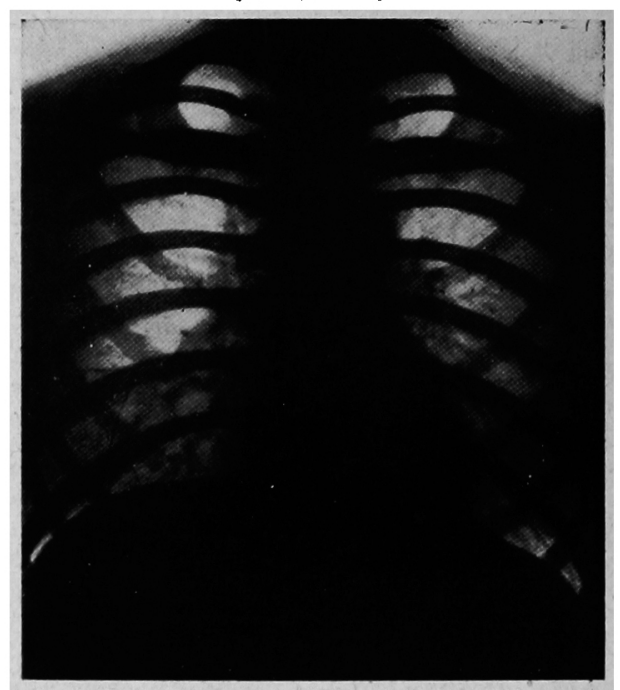

前回存在シタ䧔影八完全ニ去り, 索狀ノ隆影》

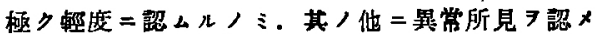
ズ.

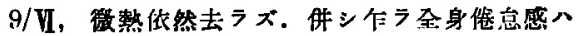
全ク去り患者ハ元氮ニシテ何等ノ苦痛ナシ。

胸部打㯖䛦上異常ナシ。

14/UI, マントー氏反應 (500 倍)：陰性.

赤论速度：1 時間 $11 ， 2$ 時間 25,24 時閂 95 ニンテ極ク輕度二促進セルテ見ル。

19/U, 微熱依然完全二消失セズ，登汗シ易キこ

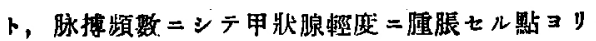

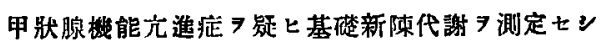
$=15.3 \%$ 圥遇.

26/VI，微熱低然去ラズ．然ル＝患者ノ策分八甚 良好，食愍，睡眠モ亦充分ニシテ體重モ濑次增加 ン胸部打聴診上異常所見証 メズ。

赤汇速应：1 時間 13,2 時間 $25 ， 24$ 時間 83. $2 / \mathbf{I}$ ，胸部 線像 (第 3 圖). 
第 3 圖 症 例 2 板某

(同 7 月 9 日)

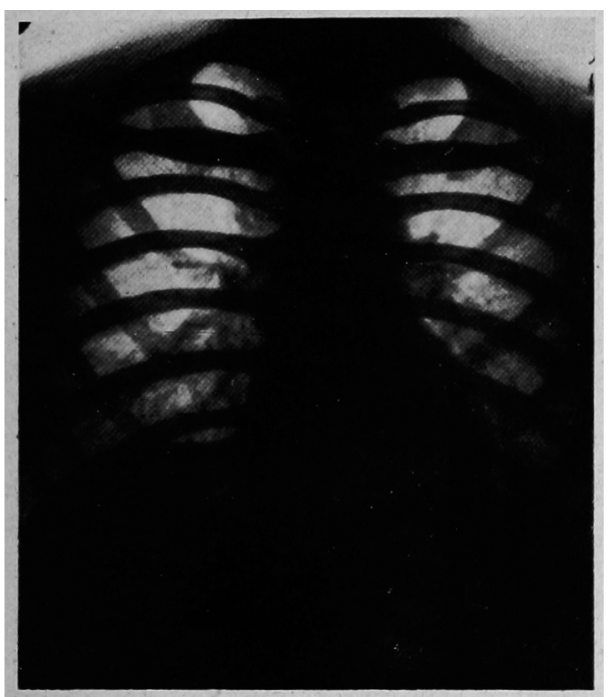

左侧下野=㑤カノ索狀隆影 7 見几他罢常所見 7 認メズ.

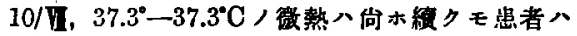
全ク健诤ニシテ入院時 =比シ體重モ䄪 $3 \mathrm{~kg}$ 增加 シ元氣二退院七リ。

退院時血液像：血色素 $68 \%$, 赤血球數 391 萬, 白血球數 7200，白血球／種別八中性嗜好性 54.0\%， 淋巴球 $34.5 \%$ ，大單核及ビ移行型 $2.5 \%$ ，肥胖細胞 $1.0 \%$ 「エォシン睹好性」 $8.0 \%$ =ンテ輕度ノ淋巴

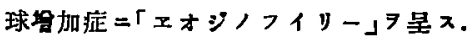

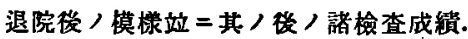

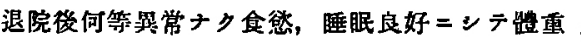
モ順次管加シ元攻二過セリト，然几二入院前，入

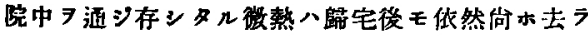
ズ，且安静ニナシ居ルモ或八多少/荤動 タナスモ 铻溫二を程ノ影率ナシト言つ。

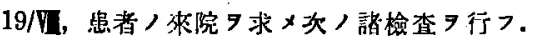

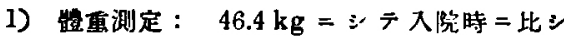
$4 \mathrm{~kg}$ 埼.

2）血液像：血色素量 70\%，胁血球數 380 萬， 白血球数 6800 ，白血球，種别八中性啫好性-41.5\%，

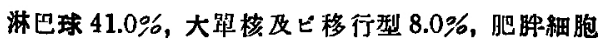

$1.5 \%$ 「ェオジン赀好」白血球 $8.0 \%$ シ テ淋巴球 聕多症站二「エオジノフイリー」フ認ム。

3） 赫沈速度：1 時間 7，2 時間 $18 ， 24$ 時間 78.

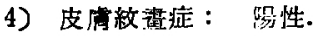

5） マントー氏反應 (100倍)：陰性。

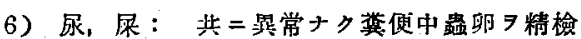
セルモコレヨ認メズ。

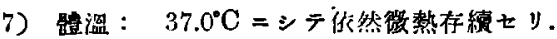

\section{總括端二考按}

余八最近當丙科教室＝於テ非常 = flüchtig ナ糟 過 コトリシ所謂一渦性肺浸潤卜考へルモ/2例 報告シタノデアルガ，以下從來影告サレタ諸家， 例 $=$ 比较ン本例ノ本態＝關シテ少シク考按 ヨ試ミ タイト思フ。

先ッ本症歌生ノ季简二關 スル諸家/統計 7 見ル $=$ Löffler ${ }^{33)}$ 八 7 月， 8 月二, Müller ${ }^{46)}$ 八夏及ヒ 秋 $=$ 多シト言 7 。寺風, 渡造雨氏60)，20 例 $=\bar{\gamma}$ 八初夏，初秋，氮候禁動/時期=多ク，岩田氏(2) ，14例デ八,月二ンり稌り差罢ナキモ5月二幾分 多イカノ感がフル，余ノ例八5月及ビ 6 月ニシテ 代等/例二一效

次二男女別二關シテ八寺阙，渡邊雨比 ${ }^{60)} 13: 7$, 岩田氏62) $12: 2$, 小松氏61) $9: 3=$ テ何レモ男子 $=$ 多 ン. 余／例八男女各 1 例デテル。

年龄的關保二就キ見 $=$ Löffler ${ }^{33)}$ 八 12 歲乃至 30 歳 $=$ 多イト迅・゙, Leitner ${ }^{32}$ ) $、 15$ 歳以下 $=コ レ$

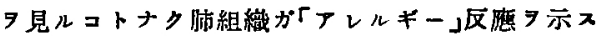
二青年期トナリ熋液性ノ感受性 $尹$ 獲得スル必要

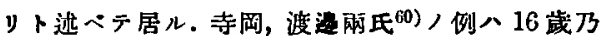
至 42 歲, 小松氏 $\left.{ }^{(1)}\right)$ ，例八 8 歲乃至 28 歲, 岩田氏 ${ }^{62}$ ，例デ八其ノ殆ドガ 19 歲乃至 32 䟠，余，2例八 16 歲及ピ 18 战デフル。併シ作ラ岩田氏ノ報告中 ニ八 60 歲ト言フ高年ノモノモ1例合マレテ居ル。

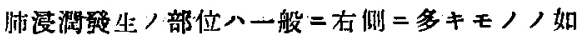

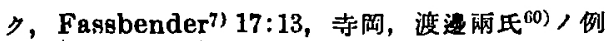


デハ18:5，岩田氏 ${ }^{(2)} 12: 2$ ト何レモ右側二多ン。 余，第 1 例八右側ナルモ符 2 例八左侧 $=$ 浸潤 7 生 シタ.

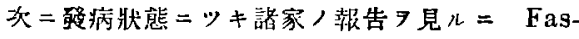
sbender ${ }^{i)}$ ガ 1926 年初 $テ$ flüchtiger Inngenprozess

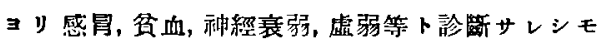

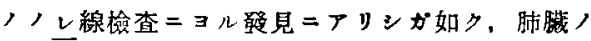
浸潤除影, 展汎ナル割二比較的輕徵ナ症狀 7 以テ 發病スル者多ク，且及一時高熱 ノ間二解熱スルモノニシテ且其ノ際患者ノ主訴无 䡒微ナルモノ多ク，假令登病當初高熱

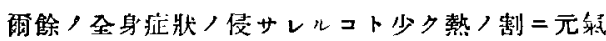

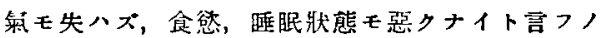

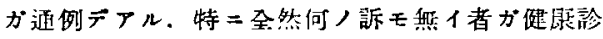

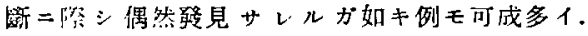
例八バ小松氏 ${ }^{(1)}$ ／例／如 $\neq 12$ 例中 8 例八何等自 覺度狀ノ無キモノナリト言フ。余ノ第 1 例八最初 「グリッペ」様高熟 7 以テ登病，第 2 例八微熱，頻

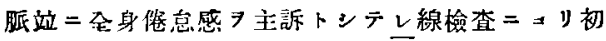
メテ酰見セラレタルモノデアル，雨者共二睡眠障 碍，食㷦不振等殆ド無ク只極ク輕度，全身像总感 フ訴へル程度=溫ギナカッタ。

赤血球沈降速度八多少促進ス几モ强度ナラス゚， 浸洞吸收サレルト共二蓃二復スルモノナルモ，上 線上浸㴸/消失 スルョリモ赤沈速度，恢復/方

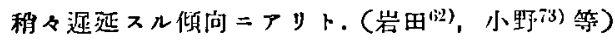
余ノ第 1 则=テハ中箱实 例二於テ八赤沈速度，促進八極夕刺度目兩例共二 浸袑吸收サレルト共二秒々夫レ二掘レテ正常二復 ンタ.

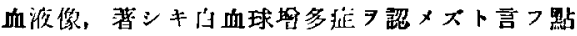
八 Leitner:2), Löffler ${ }^{33)}$, Birk u. Hager ${ }^{14)}$ 等皆

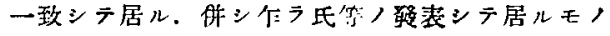

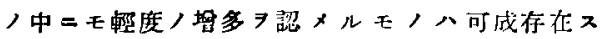
ル. 小野氏 (3) $^{73}$ 例八總テ白血球盟多症ナク岩田 氏 $^{(2)}=3$ ベ血淮榆查 7 行ヒタル7例中只 1 例輕
度ノ白血球堵等症ヨ示シタルノミニテ他八總テ正

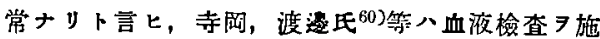

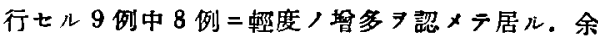

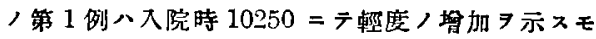
第 2 例八正常箱圆丙 $=>$ リ. 勿論第 1 例卜踓壬浸

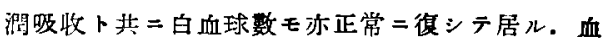
液像デ最モ問題トナルノハ「ェォジフィリー」デ アルガ、コレニ關シテハ既二記述七ル如ク今日份 意見ノ一致 7 見ズ，或八Iöffler ${ }^{33)}$, Iseitner $\left.{ }^{32}\right) ，$ 意見二從ヒコレア必登ノ條件トスル者モアリ或八 左程重視ス几要ナシト考へル者モアル，岩田氏629 =ョレパ氏 14 例中「エオシノフイリー」ヨ示シタ ルハ只さ例二過ギズュレヨ以テ一過性肺浸潤症，

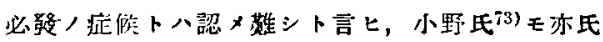
ノマ例二於テ總テ「ェオシノフィリー」ヨ認メズ

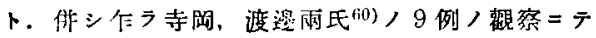
八，白血球场加期 =八「エ

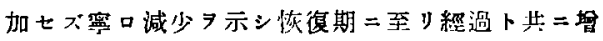
加シ後再ビ減少スル倾向アリ，從ツテ可及的路病

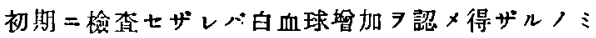
ナラプ只 1 四ノ检查ノミニテハ「ェオシノフィリ 一」ヨ看過スルコトアルベシト言フ。余ノ第 1 例

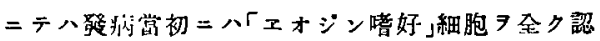

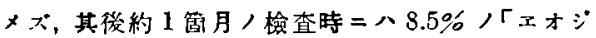

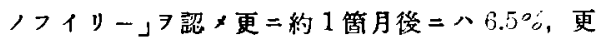

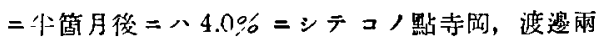
氏 $^{(i i)}=$ 一致ス，第 2 例=テ八第 1 例卜同ジク入院

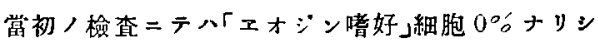

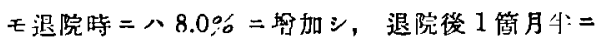

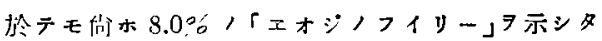

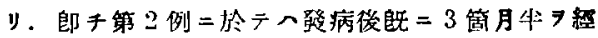

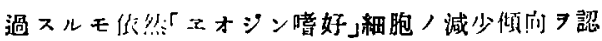
メズ，コ/點笨 1 例ト㥞子 7 界ニヘルモノト考一 ラレル.

マントー氏反應, 結核性ノモノ=照性二出几

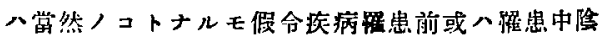
性ナルトモ路病挠 1 乃至 2 筒月，間二陽性二轉化 
スルガ如キ場合モ亦結核性ノモノト考へラレル。 非結核性ノモノニ八陽性ノコトモアリ陰性ノコト モナルノ八勿諭ナルガ路性ノ場合＝八結核性,

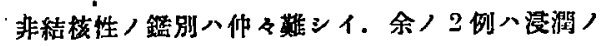
存スル間公勿諭，消能佼卜踓玉常ニマントー 氏反應陰性 ニジテ晹性二轉化シナイーニノ點へ

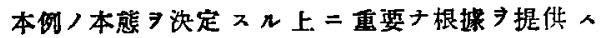
ルモノト考一ル。㧕々急性傳染病ノ細過中=一 於ケル「ッベルクリン」反磨ノ感度二閣ンテハ

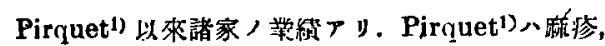
Jochmann ${ }^{4}$ 八麻疹及ビ猩紅热，百日嗄ノ時二モ

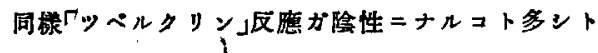
シテ種ぬノ原因 赛ゲテ居ル.Rólly2),Nothmann

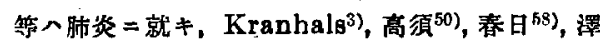
武氏80)等八「腸チフス」患者二就キピルケー氏反鷹

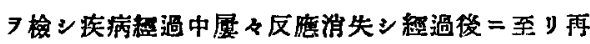

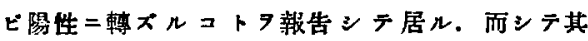

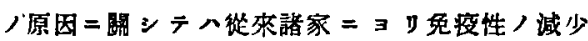
(Pirquet)，皮瓜反應力八減退 (Rolly，春日)，抗

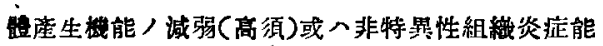

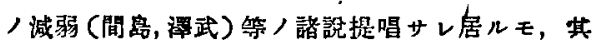
ノ何レニンロ急性傮染病ノ縟過中へ「ッバルクリ ンーフレルゲン」ガ非特累性二一時的「ナネルキ

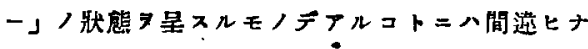

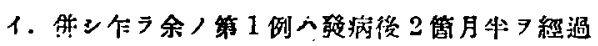
スルモコントー氏反應陰性(100.倍)ニンテ，第2例

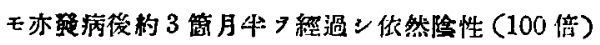

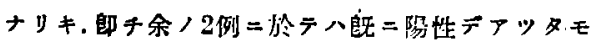

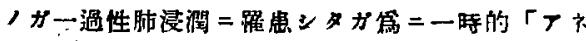

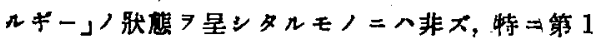

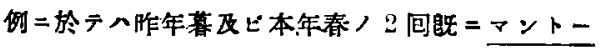
氏反應入检査の受ケ何レモ㓌性ナリン事算アリ。 之等ノ點 $コ$ 考へ余八本 2 例何レモ非結核性ノモ ノナリト考へル.

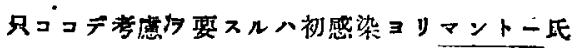
反應ガ陽性二百几迄，期間郎チEpstein，所部

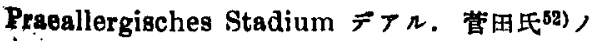

記载 化セリトノ報告アリト言フ，例へバLanger 氏八 6 乃至 11 筐月八例 7 , 熊谷教授八更 $=$ 長期閒 7 螕 テ初メテ隄性二轉化セル例ヨ新ぜリト言フ, 吻論

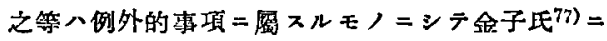
ヨレバ從來一船二信ゼラレ展ルガ如ク多クハ 3 乃

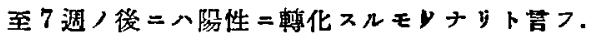
從ツテ本冽习共二非結核性ノモノナリト考フル ヘコノ點ョリ見ルモ別二不自然，感ナシ，

先ッ第 1 例八病ガ念激ニシテ恰モ「グリッべ

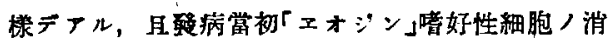
失卜輕度ノ白血球垤多症 八本例 7 非定型的肺炎 7 其ノ本意トスル一過性肺

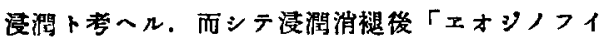

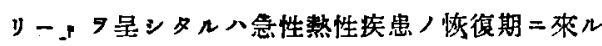
postinfektiöse Eosinophilie ト解スルノガ至賞、 ナラン.コレハス其ノ後時ノ經渦卜共 $=$ 「ォシ ン搘好」細胞ノ百分率 7 減少ン，6.5\%トナリ，更

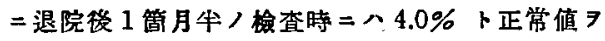
示シタル點ョリモ明カデアル。数四，粪便檢査= ‘ョルモ晹寄生费旷 7 認メズ而モ他二何等「ェォシ ハフイリー」ラ招來スルガ如キ原因モ見学ラザリ ンハ勿諭デフル.

次 $=$ 第 身サ一磪タ儿通病时期

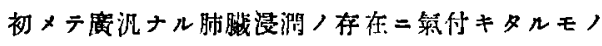

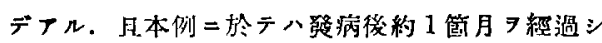
テ入院センモノナレバ其！問，血液像八知儿二由 ナキモ，入院當初ノ检查=ヨレハ白血球制八正常 ンンテ且「エオシノフィリー」フ認メプ，退院時=

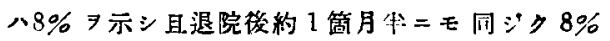

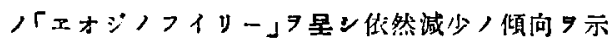

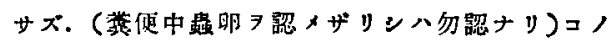
點ョリ余八本例 9 非特鼠性「アレルギー」性一渦性 肺漫潤ト信 ズ。

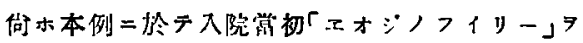
認メザリント踓モ， I合fler ${ }^{33)}$, , , leitner ${ }^{32)}$ 等 $=3$ 
ルモ同一人二就 $\neq$ テノ数国ノ揄査二於テハ常二必 ズシモ「ェォシノフイリー」ヨ認メルトヘ限ラズ, 時ニハ「エオシン」嘹好性細胞ノ甚シキ缄少 見ル。從ツテ寺岡，渡透雨氏60)，言へル如ク 1-2 包ノ血液检查ニテ八時ニ「ェオジフフィリー」テ見 逃スコトモ有り得べク，本例二块テモ登病賞初 リ数包ノ血液检查 7 施行シ居タランニ八檓二其ノ 賞時ヨッ「メオジノフィリーノノ存在 モノカトモ考へラレル。

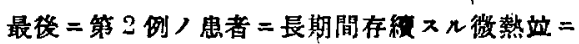
頻脈八如何二解スベギデフィカ, 勿論胸部

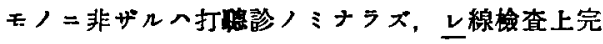

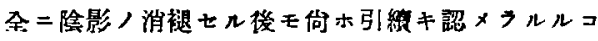

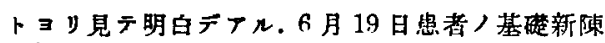
代謝测定ノ結果 $15.3 \%$ 元進 7 示シ居タル點ヨリ微 熱站 $=$ 頻脈 7 甲爿腺機能

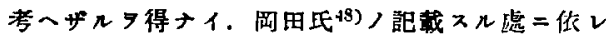
八基礎新陳代貄 $+15 \%$ - $+30 \%$ 渠八徽症, $+30 \%$ 一+50\% 轿症, +50\%-+75\% 重症, +75\% 以 上へ南篤ナリト.

即千本患者ノ基礎新棵代謝八正常人二比シ極ク 偳微ナルモ元進シテ居ルもノト見做シ得ル。而ン

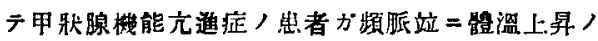

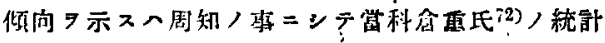
二依ルモ明カデナル。

\section{結語}

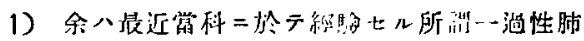

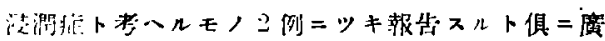
ク文镂ニ就イテ考察习試ミタ。

2）第 1 例八18歳ノ男生徒ニシテ「グリッぺ」

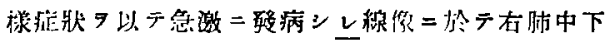

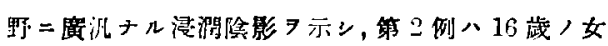

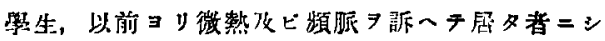

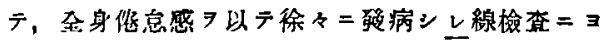

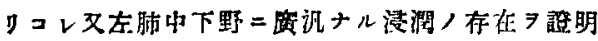

ンタ. 然ル $=$ 雨者共 $=1$ 箇月以丙二再兓七ルレ線 像二八前包ノ除影八完会二消失ンテ居タ，但ン第

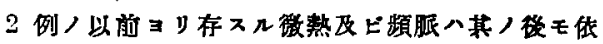
然存椣シテ居ル。

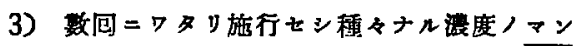
ト一氏反應八雨者共 =常=隆性ニシテ,コノ點 リ余ハ本例ノ本態トシテ結核ワ除外ン得ルモノト 考一几.

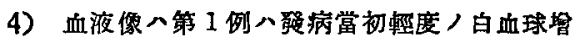
多泟

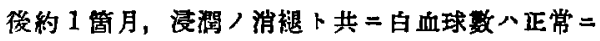

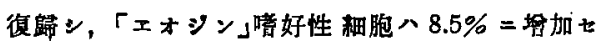
リ. 然ルニ「ェオジン」嗜好性細胞八再ビ特日ノ細 過卜共=娍少ノ傾向 7 示 更 $=$ 約牛筒月後二八 $4.0 \%$ 卜正常值二徝七り，第

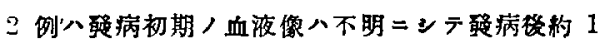
筒月ノ入院時ニハ「エォジノフイリー」ヨ势メザリ シモ其ノ後的 1 简月半ノ退院 $=$ N $8.0 \%=$ ，更

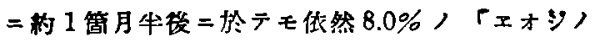
フイリー」フ政明セリ。

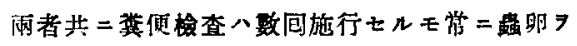
證明亡ズ，且其/他二何等「エオジノフイリー」フ 招來スルガ如ま原因方認メナカりタ。

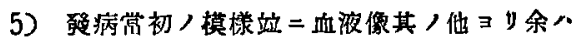

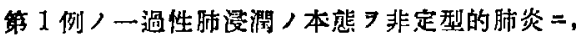
第2.例泞レルギー」性庆患二求メントス。

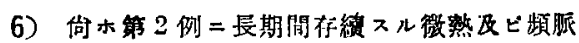

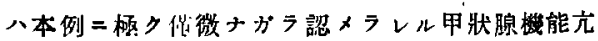
進症二起因スルも，卜考八ル。

7) 斯クテ諸家，例卜照麼シ所謂一過性肺浸潤

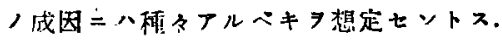

(昭和 16 年 9 月脱椋)

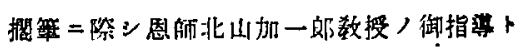
御校間 5 哚謝 $ᄌ$. 


\section{文}

1) Pirquet, Dtsch. med. Wschr. Jg. 34, S. 1297, 1908. 2) Rolly, Münch. med. Wschr. J t. 57, S. $2275,1910 . \quad$ 3) Krannhals, do. Jg. $57, \mathrm{~S}$. 838, 1910. 4) Jochmann, Lehrb. d. Infektkrht. (Berlin) 1924. 5) Redeker, Beitr. Klin. Tbk. Bd. 50, S. 88, 1924, 6) Assmann, do. Bd. 64, S. 578, 1926. 7) Fassbender, Z. Tbk. Bd. 44, S. 35, 1926. 8) Assmann, Dtsch. med. Wgchr.Jg. 53, S. 781, 1927. 9) Kleinschmidt, Beitr, Klin. Tbk. Bd. 65, S. 369, 1927. 10) Sonnenfeld, do Bb. 69 , S. 209,1928 . 11) Schellenberg, do Bd. 69 ' S. 498, 1938. 12) Ulriei, do Bd. 70, S. 159 , 1928. 13) Curschmann, do Bd. 69, S. 540, 1928. 14) Birk,.u. Elager, Münch. med. Wschr.Jg. 75, S. 1991 u. 2057, $1928 . \quad$ 15) A8smann, Ergeb. Tbk. fosch. Bb. 1, S. 115, $1930 . \quad$ 16) Zdansky, Fschr. Röntgenstr. Bd. 43, S. 576,1930 . 17) Redeker, Ergeb. Tbk. forsch. Bd. 11!, S. 41, 1932. 18) Löffler, Beitr. Klin. Tbk. Bd. 79, S. 338 , u. 566, 1932. 19) Boytinck, do Bd. $30, \mathrm{~S}$. 67, 1932. 20) Kellner, dó Bd. 81, S. 639, 1932. 91) Hochstetter, Z. Tbk. Bd. 68, S. 17, 1933. g2) Leitner, do Bd. 66, S. 226, 1933 . 23) Wild u. Loerscher, Schweiz. med. Wschr. Jg. 15, S. 829, 1934. 24) Tendeloo, Zit. Sinmon in Ergeb. Tbk. forsch. Bd. 4, S. 1, 1934 25) Simmon, Ergeb. Tbk. forsch. Rd. 4, S. 1, 1934. 26) Engelbreth-Holm, Klin. Wschr.Jg. 13, \$. 1605, 1934. 27) Kellner, Beitr. Klin. Tbk. Bd. 84, s. 1, 1934. 28) Heesen, do Bb. 84, S. 583, 1934 . 29) Brïuning, Z. Tbk. Ed. 73, S. 174, 1935 . 90) Engel, Beitr. Klin. Tbk. Bd. 87. S. 239, 1935. 31) Eliasberg, u. Neuland, Zit. Rässel in Virchows Auch. Bd. 269, S. 1, 1936 . 39) Leitner, Beitr. Klin. Tbk. Bd. 88, S. 388, $1936 . \quad$ 33) Löffler,
Schmeiz. med. Wschr. Jg. 17, S. 1069, 1936. 34) Geiger, dóJğ. 17, S. 1076, 1936. Virschows Arch. Bd. 296, S. 1, 1936. 36) Wild, Schwei\%. med. Wschr. Jg. 17, S. 1076, 1936. 37) Rohner, do Jg. 17, \$, 1077, $1936 . \quad$ 38) Engel I1. Desider, Beitr. Klin. Tbk. Bd. 87, S. 239, 1936. 39) Wieland, Schweiz. med. Wsc!r .J. 17, S. 1076, 1936. 40) Steiger, Dtsch. Tblk. bl. Jg. 11, S. 154, 19:37. 41) Rondon, Wien. med. Wschr. Jg. 87 , S. 1127,1937 . 42) Meyer, Dtsch. med. Wschr. Jg. 63, S. 1809, 1937. 43) Müller, do Jg. 64, S. 1286, $1938 . \quad$ 44) Eversbusch, Med. Klin, Jg. 35, S. 745, $1939 . \quad$ 45) Müller, Beitr. Klin. Tbk. Bd. 92, S. 254, $1939 . \quad$ 46) Syller, Klin. Wschr. Jg. 19, S. 753,1940 . 47) 网田, 蚠

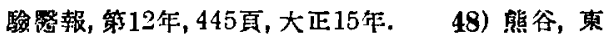
京整事新誌，第2545號，1915頁，昭和2年４9）亮 須，日本傳染病學䧴誌，第 5 怣，1006頁，昭和 6 年.

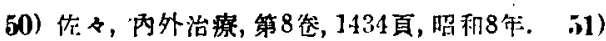

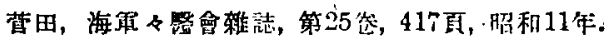

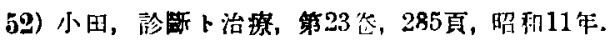

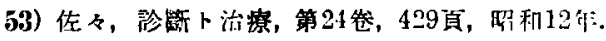

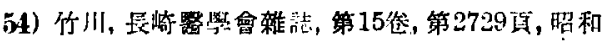

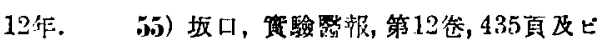

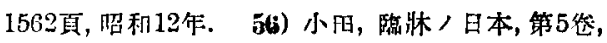

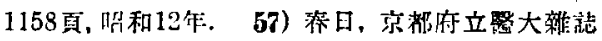

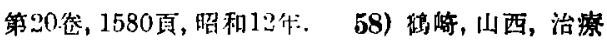

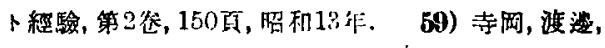

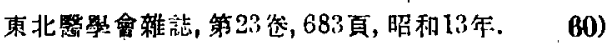
小松，結核，第16忞，77留，昭和13年。61）岩田，

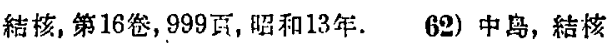

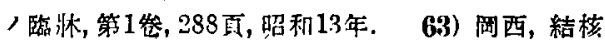

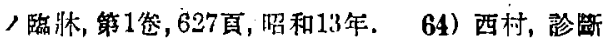

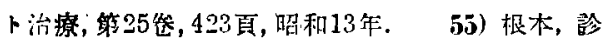

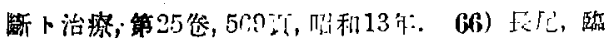


斨ノ日本, 第7卷, 1037頁, 昭和14年.

67）敬绮,

頁, 昭和15年.

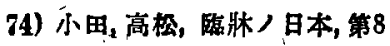

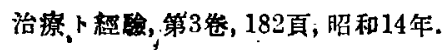

68) 竹谷,

卷, 1498頁, 昭和15年,

75) 日野原, 日本㗄染病

十全會雜誌，第44兊，3494頁，昭和14年。69）平田，

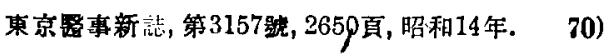

學雜誌，第14卷, 339 頁，昭和15年.

76) 金子、内

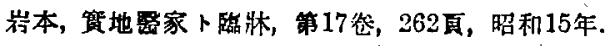
科學(金原商店知行)。昭和15年版。

77) 河合,"兒

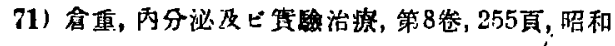

科雜誌，第47卷, 768面，昭和16年:

78) 近菏, 领

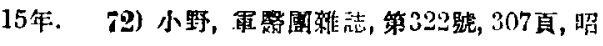

治療，第28告，811面，昭和16年。

79) 澤武,-

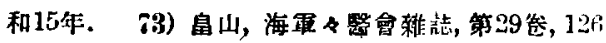

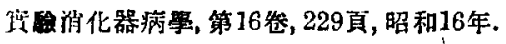

80)

山田，治療及ビ虎方，第22甞，985頁，昭和16年。

Aus der Inneren Klinik der Medizinischen Universität, Okayama.

(Dir. : Prof. Dr. K. Kitayama)

Zwei Fälle der sog. fliichtigen Lungeninfiltrierumg.

Von

Dr. K. Hiraki.

Eingegangen am 17. Januar 1948.

Bericht und Besprechung mit Berücksichtigung einschlägier Literatur über 2 Fälle der sog. flüchtigen Lungeninfiltrierung, die der 'Verf. in unserer Klinik in der letzten Zeit beobachten konnte.

Der I. Fall war ein 18 jähriger. Schüler, der mit grippenartigen Symptomen in Stür: mischem Verlaufen erkrankt war. Das Röntgenbild lieferte auf dem mittleren und dem. unteren Feld der rechten Lunge einen ausgedehnten Infiltratschatten. Im Ir. Fall handelte es sich um eine 16 jährige Schülerin, die von jeher über ein geringes Fieber und Tachycardie zu klagen hatte und dann mit allgemeiner Mattigkeit allmählich erkrankt war. Bei röntgenologischer Untersuchung des letzten Falles machte sich ebenfalls ein ausgedehnter Infiltratschatten auf dem mittleren und dem unteren Feld der linken Lunge bemerkbar.

In den beiden Fällen ist der Röntgenșchatten jedoch, als der Verf: vor einem Monate untersuchte, nicht mehr erkennbar gewesen. Das geringe Fieber und die Tachycardie des II. Falles hingegen sind noch bestehengeblieben.

Die wiederholt angestellte Mantouxsche Tuberkulin-Reaktion in wechselnden Verdünnungen fiel in den beiden Fällen jedesmal negativ aus. Daraus hat der Verf. den Schluss gezogen, dass man bezüglich des Wesens der vorliegenden Fälle an die Tuberkulose. nicht mehr zu denken braucht. 
Was das Bldtbild anbetrifft, so zeigte der I. Fall im Frühstadium der Erkrankung eine' leichte Leukozytose, aber keine Eosinophilie. Nach Ablauf ca. einen Monates kehrte die Leukozytenzahl mit dem Rücktritt der Infiltration allmählich zur Norm zurück, die eosino. philen Leukozyten indes vermehrten sich auf 8,5\%. Diese Vermehrung machte aber im ‘ Verlauf der Zeit einer Tendenz der Abnahme Platz und nach einelu weiteren Monat verringerten sich die Leukozyten auf 6,5\%, um nach ca. einem halben Monat zu 4,0\%, zum normalen Wert, zurückzukommen. Beim II. Fall war das Blutbild im Frühstadium der Erkrankung nicht bekannt. Als die Kranke ca. ein Monat nach der Erkrankung in die Klínik aufgenommen worden war, liess sich keine Eosinophilie festzustellen. Bei der Entlassung von der Klinik jedoch, die ungefähr nach weiteren anderthalben Monaten geschah; machten die eosinophilen Leukozyten $8,0 \%$ der gesamten weissen Zellen aus, was noch anderthalbe Monate nach dem Verlassen der Klinik hartnäckig fortbestand.

In den-beiden Fällen wurde die Kotprobe mehrere Male vorgenommen, wobei aber nicht nur keine Parsiteneier, sondern auch keine Ursache für die Eosinophilie nachgewiesen wurden.

Aus dem Verlauf des Frühstadiums sowie dem Blutbild usw. schliesst der Verf., dass es sich im I. Fall in bezug auf die flüchtige Lungeninfiltrierung um atypische Pneumonie, im II. Fall um allergische Erkrankung handelt. Was aber das andauernd fortbestehende geringe Fieber und die Tachycardie des II. Falles anbelangt, so liegt die Annahme nahe, dass an diesen Erscheinungen der Hyperthyreoidismus, wenn er auch nur in geringem Masse beobachtet wurde, schuld sein muss.

(Autoreferat) 